\title{
The Determinants of Private Commercial Banks Profitability: In the Case of Selected Ethiopian Private Banks
}

\author{
Moges Endalamaw Yigermal \\ Monetary and Financial Analysis Directorate, National Bank of Ethiopia, Addis Ababa, Ethiopia
}

Email address:

Mogeshabesha@gmail.com, gebre09meskel@gmail.com

To cite this article:

Moges Endalamaw Yigermal. The Determinants of Private Commercial Banks Profitability: In the Case of Selected Ethiopian Private Banks. International Journal of Economic Behavior and Organization. Vol. 5, No. 1, 2017, pp. 25-35. doi: 10.11648/j.ijebo.20170501.15

Received: July19, 2016; Accepted: January 29, 2017; Published: March 4, 2017

\begin{abstract}
The main objective of the paper is to analyze the impact of bank specific and macro-economic factors on the profitability of selected Ethiopian private commercial banks over the period of 2005 to 2014. To meet the objective, both descriptive and random effect panel econometrics method of data analysis has been employed. The study uses both return on asset (ROA) and return on equity (ROE) as a measurement for banks profitability. Private Banks profit after tax gets increasing year after year and their ROA is found to be three percent on average. The deposit share of private commercial banks reached above 30 percent in 2014, while it was only 10 percent in 2000 . The panel econometrics result shows that, the variable bank size and GDP growth rate has a positive and significant impact on private commercial banks ROA and ROE. While, interest rate spread has a negative and significant impact. The variable Loan to deposit ratio has negative and significant impact on banks ROA while, it has no effect on their ROE. Inflation also an important variable in explaining ROA at 10\% significant level but, it has no effect on ROE. The other important variable in explaining ROE is loan concentration index it has positive and significant impact on banks ROE. But, it does not significantly explain ROA. As a recommendation the significant and positive impact of Bank size can be taken as a good signal for commercial banks to merge and to have scale advantage. The significant impact of macro-economic variables in explaining banks profit is an indicator to designed policies that promote sustainable output growth and controlling inflation to have stable banking sector.
\end{abstract}

Keywords: Profitability, Determinant, Private Commercial Banks

\section{Introduction}

Profitability is a bank's first line of defense against unexpected losses, as it strengthens its capital position and improves future profitability through the investment of retained earnings [6].

Whether profitability is measured as returns on assets, returns on equity, or net interest margins Commercial banks appear very profitable in Sub-Saharan Africa (SSA). Average returns on assets were about 2 percent over the last 10 years, significantly higher than bank returns in other parts of the world. Bank profits are an important source of equity and it promotes financial stability. If bank profits are reinvested, this should lead to safer banks, and, consequently, high profits could promote financial stability [7].

As far as the ownership of commercial banks is considered privately owned banks earn higher returns compared to publicly owned ones. Privately owned banks may be more profitable than state-owned due to imperfectly designed incentives or because public banks may have objectives other than profit or value maximization. The more profitability of private banks than the public ones a signal to encourage privatization in the banking sector, but only to the extent that reinvestment of the profits can be effectively encouraged [7].

The profitability of Ethiopian commercial banks as measured by return on asset (ROA) was found to be higher and above than the Sub-Saharan Africa (SSA) average returns on asset. The average Return on Asset for Ethiopian commercial banks was three percent on average terms.

The premise also holds true in Ethiopia, while we take return on asset as a measurement of commercial banks profitability. Privately owned banks found to have higher 
average return on asset than publicly owned banks (Constriction and business bank \& commercial bank of Ethiopia). For instance if we see average ROA for the year 2011 to 2013, average ROA for private banks found to be above three percent in annual basis while it was below three percent for the public ones.

\subsection{Statement of the Problem}

There is no doubt that profitability is essential for a bank to maintain ongoing activity and for its investors to obtain fair returns. Even though the primary objective of every commercial bank is to make profit, profitability is not the same across commercial banks. This because of profitability is determined by different factors such as factors specific to the bank and Macro-economic determinants.

Factors internal to the bank such as capital adequacy and liquidity ratio have a significant impact over the profitability of the banks. External factors, inflation, total assets of the deposit money banks divided by the GDP, and stock market capitalization to total assets are significantly associated with commercial banks profitability in Jordan [10].

According to reference [9], on the determinants of commercial banks profitability over the time period from 2004-2010, employed the impact of both internal and external determinants of banking profitability finds capital strength of a bank, assets quality and bank size has direct association with banks profitability. On the other hand inflation and NIGI affects profitability of banks negatively. The study uses return on equity (ROE) and net-interest margin (NIM) as a measurement for banks profitability.

IMF working paper (2009) on the Determinants of Commercial Bank Profitability in Sub-Saharan Africa conclude that Bank-specific and macroeconomic risk factors are the most important explanations for banks' high returns in SSA.

The Sub-Saharan Africa's (SSA) commercial banks average returns on assets were about 2 percent from the period 1998-2006, significantly higher than bank returns in other parts of the world. While the average returns on assets for Ethiopian commercial banks were even higher than the Sub-Saharan average, it was about 3 percent on average ${ }^{1}$.

Irrespective of many challenges that private commercial banks in Ethiopia has faced, they were found to be more profitable and having high return on asset, even above the SSA average. But profitability across individual banks is not the same. This variation of profitability across private commercial banks, inspire everyone to raise the question of "why profitability is vary across private commercial banks and what factors contribute to this variation and determine the profitability of private commercial banks. Thus, the main target of this paper is to determine factors that affect the profitability difference between private commercial banks in Ethiopia.

Most Previous studies on the profitability of commercial

1 The IMF, 2009 working paper shows that the average returns on asset for Ethiopian commercial banks were slightly above 3 percent. banks used merely ROA or ROE as a measurement for banks profitability. But, this study takes into consideration both ROA and ROE as an Endogenous factor while, determining banks profitability.

\subsection{Scope and Objective of the Study}

The scope of the study is bounded on the effect of bank specific and macro -economic factors on the profitability of selected private commercial banks in Ethiopia over the year 2005 to 2014. Specifically the paper attempts to address the following objectives:-

- The impact of bank size, market concentration, credit risk and Bank branch on the determination of banks return on asset (ROA).

- Whether wealth (GDP per capita), economic growth (GDP growth rate) and inflation (CPI growth rate) has an impact on private commercial banks profitability in Ethiopia.

\subsection{Hypothesis of the Study}

Following from the objective of the study, we seek to test the following hypothesis:

- There is no direct relationship between bank specific variables and bank's ROA \& ROE

- There is no a direct relationship between macroeconomic variables and bank's ROA\& ROE

\subsection{Organization of the Paper}

The paper organized under five chapters. The first chapter deals with the introduction part which contains introduction, statement of the problem, objective, scope of the study. The second chapter includes both theoretical and empirical reviews. The third chapter covers methodologies and model specification of the study. The fourth chapter is about data analysis. The final chapter, which is Chapter five, was designed to provide conclusion and policy recommendation based on the study obtained from analysis.

\section{Literature Review}

This section of the paper reviews both conceptual and empirical literature about banks profitability and banks profit determinant factors.

Among the large set of performance measures for banks used by academics and practitioners alike, a distinction can be made among traditional, economic and market-based measures of performance.

\subsection{Traditional Measures of Performance}

Traditional performance measures are similar to those applied in other industries, with return on assets (RoA), return on equity (RoE), Net interest margin (NIM) being the most widely used.

The return on assets (RoA) is the net income for the year divided by total assets, usually the average value over the year. 
Return on assets = net income (profit after tax) / average total assets

Return on assets is an internal performance measure of shareholder value, and it is by far the most popular measure of performance, since:

- It proposes a direct assessment of the financial return of a shareholder's investment;

- It is easily available for analysts, only relying upon public information; and

- It allows for comparison between different companies or different sectors of the economy.

Return on equity is sometimes decomposed into separate drivers: this is called the "Dupont analysis", where $R o E=$ (result/turnover)*(turnover/total assets) *(total assets/equity)

The first element is the net profit margin and the last corresponds to the financial leverage multiplier.

Return on equity = net income / average total equity

Finally, the net interest margin is a proxy for the income generation capacity of the intermediation function of banks.

Net interest margin = net interest income / assets (or interest-bearing assets)

\subsection{Economic Measures of Performance}

The economic measures of performance take into account the development of shareholder value creation and aim at assessing, for any given fiscal year, the economic results generated by a company from its economic assets (as part of its balance sheet). These measures mainly focus on efficiency as a central element of performance, but generally have high levels of information requirements.

Two sets of indicators can then be identified amongst economic measures of performance:

A. Indicators related to the total return of an investment, based on the concept of an

"Opportunity cost"; the most popular one being economic value added (EVA).

$\mathrm{EVA}=$ return on invested funds - (weighted average cost of capital * invested capital)

- (weighted average cost of debt * net debt)

B. Indicators related to the underlying level of risk associated with banks' activity.

\subsection{Market-Based Measures of Performance}

Market-based measures of performance characterize the way the capital markets value the activity of any given company, compared with its estimated accounting or economic value. The most commonly used metrics include:

- The "total share return" (TSR), the ratio of dividends and increase of the stock value over the market stock price;

- The "price-earnings ratio" $(\mathrm{P} / \mathrm{E})$, a ratio of the financial results of the company over its share price;

- The "price-to-book value" (P/B), which relates the market value of stockholders' equity to its book value;

- The "credit default swap" (CDS), which is the cost of insuring an unsecured bond of the institution for a given time period.

\subsection{Determinants of Bank Profitability}

In the literature, bank profitability, typically measured by the return on assets (ROA) and/or the return on equity (ROE), is usually expressed as a function of internal and external determinants. Internal determinants are factors that are mainly influenced by a bank's management decisions and policy objectives. Such profitability determinants are the level of liquidity, provisioning policy, capital adequacy, expenses management and bank size. On the other hand, the external determinants, both industry-related and macroeconomic, are variables that reflect the economic and legal environment where the credit institution operates.

\subsection{Macroeconomic Determinants}

Commercial Banks profitability is expected to be sensitive to macroeconomic variables. This paper use GDP growth and GDP per capita as a control for economic growth and wealth effects, which is expect to have a positive influence on bank profitability. As GDP growth slows down, and, in particular, during recessions, credit quality weakens, and defaults increase, thus reducing banks return.

Reference [7] suggests macroeconomic variables significantly affect banks' profitability in Africa. In particular, inflation has a positive effect on bank profits, which propose that banks forecast future changes in inflation correctly and promptly enough to adjust interest rates and margins. And the also find a positive impact of output growth on bank profitability.

The paper also accounts inflation, as measured by the current period CPI growth rate, as a macroeconomic variable that affect the level of banks profitability. And it's expected to have a positive effect on bank profitability. The extent to which inflation affects bank profitability depends on whether future movements in inflation are fully anticipated, which, in turn, depends on the ability of firms to accurately forecast future movements in the relevant control variables. For instance reference [4] has proposed a positive relation between inflation and long term interest rates with bank performance.

\subsection{Determinants Specific to the Bank}

Credit risk: can be measured by using the ratio of loans to deposits and short-term funding, since this provides a forward-looking measure of bank exposure to default and asset quality deterioration. It is expected to have a positive impact on the level of banks profit.

Capital: should be an important variable in determining bank profitability, although in the presence of capital requirements, it may proxy risk and also regulatory costs. In imperfect capital markets, well-capitalized banks need to borrow less in order to support a given level of assets, and tend to face lower cost of funding due to lower prospective bankruptcy costs. Also, in the presence of asymmetric information, a well-capitalized bank could provide a signal to 
the market that a better-than-average performance should be expected.

Bank Size: could be important variable in determining banks return on asset. It can be measured using the logarithm of total assets and their square ${ }^{2}$. And it is expected to have positive impact on banks return. Larger banks may have efficiency gains due to economies of scale. This would imply lower costs for larger banks that they may retain as higher profits.

Market concentration: is expected to be a main determinant of banks return. This is because banks in more concentrated markets should be capable of adjusting spreads in response to unfavorable changes in the macroeconomic environment to leave returns unaffected. And it is measured by the ratio of each bank's total outstanding loans to the net domestic credit of the country.

Number of bank branches: the total number of branches of each private commercial bank opened during the review period. As researched by previous scholars adequate levels of branch expansion have positive impacts on both cost and profit efficiencies of banks for example see Reference [11].

According to reference [14] that management decisions, especially regarding loan portfolio concentration, were an important contributing factor in bank performance. Researchers frequently attribute good bank performance to quality management. Management quality is assessed in terms of senior officers ${ }^{e e}$ awareness and control of the banks policies and performance.

Reference [5] found that the profitability of European banks is influenced not only by factors related to their management decisions but also to changes in the external macroeconomic environment. Equity to assets ratio has consistently the same sign and level of significance suggesting that banks with greater levels of equity are relatively more profitable. The loans to assets ratio appears to be inversely related to banks return on assets. This implies that banks which have large non-loan earning assets are more profitable than those which depend more heavily on assets. Also, find a positive effect of the concentration and/or market share variables on bank profitability. The level of interest rate has a positive effect, while the variability of the interest rates and the growth of GDP rates negative.

Reference [1] suggested that the profitability of Saudi banks has a positive and significant correlation with total investment to total assets ratio, total equity to assets ratio and liquidity risk, in addition, there has been a negative and significant correlation with net credit facilities to total assets ratio, net credit facilities to total deposits ratio, costto-income ratio and size variables. Whereas, the profitability of the Jordanian banks has a significant positive correlation with liquidity risk, net credit facilities to total assets ratio, total equity to assets ratio and net credit

2 IMF working paper by Valentina Flamini, Calvin McDonald, and Liliana Schumacher (2009) use logarithm of total assets and their square as a proxy for bank size. facilities to total deposits ratio variables. Furthermore, there has been a negative and significant correlation with cost income ratio, total investment to total assets ratio and bank size on profitability. It is worth mentioning that, the relationship between profitability and bank size is negative in both models.

As indicated by reference [8] on the determinants of profitability in Spain, Italy, France, Denmark and the UK, for the period $1992-1998$. They found that the profitability was a positive relationship with the capital-assets ratio. Furthermore, the authors found a positive relationship between profitability with the importance of off-balancesheet business in a bank's portfolio for the UK, but either neutral or negative elsewhere.

Reference [13] made analysis on profitability of Kenya's top six commercial banks over the period 2008-2013, by using generalized least squares method and the researcher tries to see the impact of internal determinants of banking profitability and the study uses (ROA) as a measure for profitability. The findings revealed that bank size, capital strength, ownership, operations expenses, diversification do significantly influence profitability of the top six commercial banks.

Reference [2] made a study on the impact of macroeconomic factors on the profitability of domestic and foreign commercial banks in Malaysia. They used unbalanced panel data set of 16 commercial banks and they applied panel data regression technique over the period of 2004-2011. Their finding suggests, external factors such as inflation, interest rate and GDP have a positive impact on all commercial bank's return on assets and stock market development influence bank's profit negatively.

The study on the determinants of Banks Profitability operated in Pakistan for the period from 2009-2012 using panel data estimation technique of common, fixed, random effect model and his finding revealed a positive impact of capital and bank size over the profitability of banks. The study also finds loan loss provision has negative and significant effect on the profitability of Pakistan banks [9].

Reference [12] on the determinants of commercial (both public and private) banks profitability in Ethiopia there by employing ordinary least square regression method, finds the positive and significant effect of Bank size, capital adequacy and gross domestic product on bank's profitability. And also he finds a negative and statistically significant impact of liquidity risk, operational efficiency; funding cost and banking sector development on banks' profitability.

Reference [3] made a study on the profitability of Ethiopian commercial banks there by using Net Interest Margin (NIM) as a measure of profitability. They had used multiple regression analysis to estimate the effect of variables used on the profitability of banks and their finds showed that number of branches, total loan to total deposit ratio and ownership structure have a positive and statistically significant impact on the profitability of Ethiopian commercial banks. 


\section{Research Methodology}

\subsection{Source and Type of Data}

The data for different variables in this study was obtained from National Bank of Ethiopia for the period 2005-2014. Because of the short history of private commercial banks it is impossible to find data for all private commercial banks operated in Ethiopia. And then we obliged to select a few banks based on their years of establishment. Accordingly data for this paper was from Awash International Bank, Dashen Bank, Bank of Abyssinia, Wegagen Bank, United Bank, Nib International Bank and Cooperative Bank of Oromia.

\subsection{Method of Data Analysis}

Here, in this study both descriptive and panel econometrics method of data analysis has been employed to discover the effects of bank specific and macroeconomic factors on the profitability of Ethiopian private commercial banks. Descriptive data analysis has been used to describe the profitability trend of commercial banks that has been used under the study and to show summary statistics for variables used under the model. For the econometrics part, random effect panel data analysis has been used.

\subsection{Model Specification}

The empirical results of previous researchers indicate some significant variables that determine the profitability of commercial banks for different countries. Reference [1], [2], [8], [9] and [13] made a study to test the significance effect of bank specific and macro-economic factors on commercial banks profitability. The model for this study used variables that have significant effect on the profitability of commercial banks as researched by different scholars for different countries to see whether or not the study holds true for Ethiopian private commercial banks. Far from previous researchers the present study includes additional variables as determinant factor for the profitability of banks such as; the interest rate spread, bank branch and lending concentration index.

Though, the major objective of this paper is to assess the effect of Bank specific and macro-economic determinants on the profitability of private commercial banks of Ethiopia, measured by return on asset (ROA) and (ROE) we can develop the corresponding two balanced panel model here as follows:

$$
\pi_{\mathrm{it}}=\beta_{0}+\Sigma_{\mathrm{b}} \gamma_{\mathrm{b}} \mathrm{X}_{\mathrm{it}}^{\mathrm{b}}+\Sigma_{\mathrm{m}} \beta_{\mathrm{m}} \mathrm{X}_{\mathrm{t}}^{\mathrm{m}}+\varepsilon \mathrm{it}
$$

Where;

$\pi_{\mathrm{it}}$ is the profitability of bank $\mathrm{i}$ for period $\mathrm{t} ; \beta_{0}$ is the constant term; $X^{b}{ }_{i t}$ and $X^{m}{ }_{t}$ represents factors specific to each bank for period $\mathrm{t}$ and macroeconomics determinants, respectively.

$\gamma_{\mathrm{b}}$ and $\beta_{\mathrm{m}}$ are the coefficients for bank specific and macroeconomic determinants respectively.

$$
\varepsilon i t=\mu \mathrm{i}+\text { vit }
$$

$\mu i=$ the unobserved effect of bank-specific factors, where it is assumed to be time invariant and specific to each individual observation (each bank).

$v i t=$ the idiosyncratic error (the usual error term), which is assumed to be varies randomly across both individuals and time periods.

Accordingly there by incorporating bank specific factors (such as bank size, loan to deposit ratio, number of bank branches, interest rate spread and loan concentration index) and macro-economic factors (GDP growth rate, GDP per capita and inflation), to equation (1) we can write the final regression model as follows;

$$
\begin{gathered}
\pi_{i t}=\beta_{0}+\beta_{1} \mathrm{BS}_{\mathrm{it}}+\beta_{2} \mathrm{LDR}_{\mathrm{it}+} \beta_{3} \mathrm{LCI}_{\mathrm{it}+} \beta_{4} \mathrm{IRS}_{\mathrm{it}}+\beta_{5} \mathrm{BB}_{\mathrm{it}}+\beta_{6} \mathrm{GDPgr}_{\mathrm{t}} \\
+\beta_{7} \mathrm{GDPpc}_{\mathrm{t}}+\beta_{8} \mathrm{CPI}_{\mathrm{t}}+\varepsilon \mathrm{it}
\end{gathered}
$$

Where, $\beta 1 \geq 0, \beta 2 \leq 0, \beta 3 \geq 0, \beta 4 \geq 0, \beta 5 \geq 0, \beta 6 \geq 0, \beta 7 \geq 0, \beta 8 \leq 0$ $\pi_{\text {it }}$ Indicates return on equity (ROE) and Return on asset (ROA), for bank $\mathrm{i}$ at a time $\mathrm{t}$.

Table 1. Variable Description.

\begin{tabular}{lll}
\hline List of Variables & Description & Notation \\
\hline Return on asset & The ratio of profit after tax and consecutive years average total asset & ROA \\
Return on equity & The ratio of Equity and consecutive years average total asset & ROE \\
Bank size & Natural logarithm of each banks total asset & BS \\
Loan- deposit ratio & The ratio of each banks total loan and total deposit & LDR \\
Loan concentration index & Each banks total outstanding loans to net domestic credit to the country & LCI \\
Bank branch & Branch number of each bank & BB \\
Interest rate spread & The difference between loan interest rate and deposit interest rate & IRS \\
GDP growth rate & Annual output growth rate & GDPgr \\
GDP per capita & Annual GDP per capita growth rate & GDPpci \\
CPI growth rate & Annual consumer price index growth rate & CPI \\
\hline
\end{tabular}

\section{Discussion and Analysis}

\subsection{Descriptive Data Analysis}

Since 2000 the deposit shares of private commercial banks were not significant and it was only 10 percent of the total deposit hold by commercial banks. The remaining 90 percent were covered by state owned commercial banks and the lion share was held by commercial bank of Ethiopia. The lowest share covered by private commercial banks was mainly due to poor competition among private and commercial bank of 
Ethiopia (privilege given for CBE) and the perception of the depositors also contributed for it. Afterwards the deposit share of private banks gets increasing and reached 40 percent of the total deposit hold by commercial banks at the year 2010. This is mainly due to the entrance of new private commercial banks in to the market and the reach ability of banks to the society through branch opening. The deposit share of private banks gets decreasing after 2010 and reached 30 percent of the total at the end of 2014 (Figure 1).

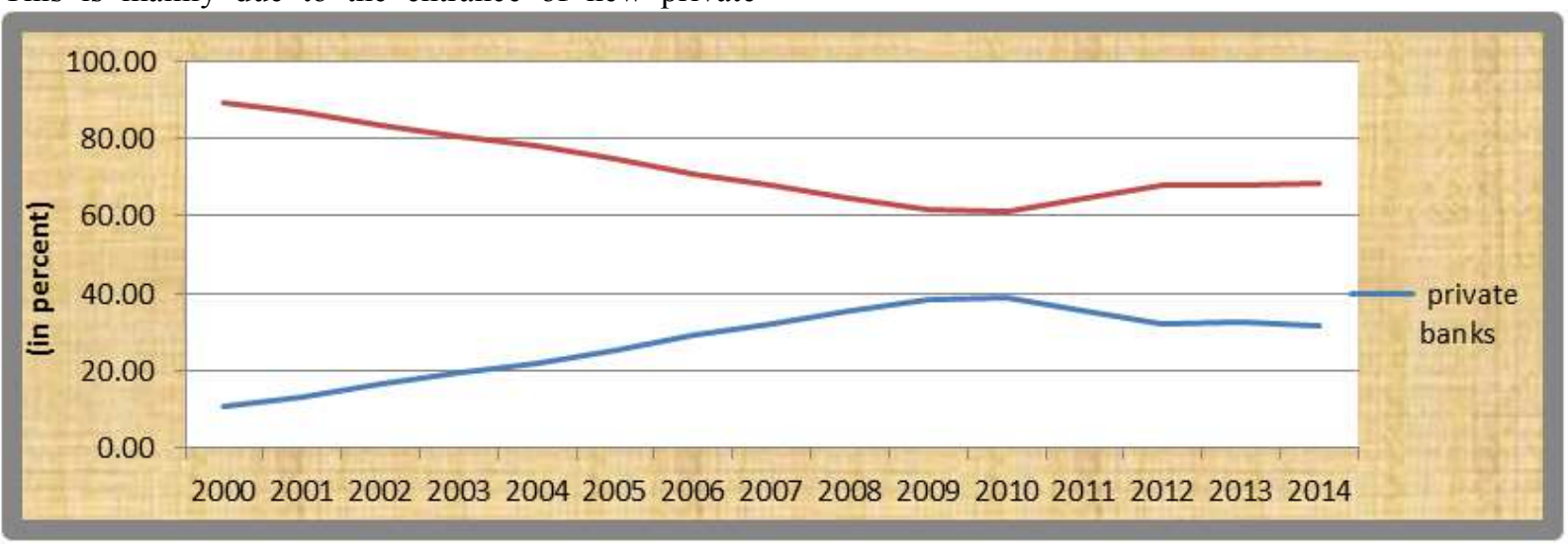

Source: own computation

Figure 1. Deposit share of commercial banks by ownership.

Commercial banks (both private and state owned) invest in excessive branch expansion and the total number of bank branches opened reached above 2,700 in 2015, while it was below 400 in 2014. Of these private commercial banks opened a total of 1600 branches in 2015. As the annual report of NBE (2014/15) shows, bank branch to total population ratio declined to 1:33,448.25 in 2014/15, while it was 1:39,833.84 people last year (Figure 2).

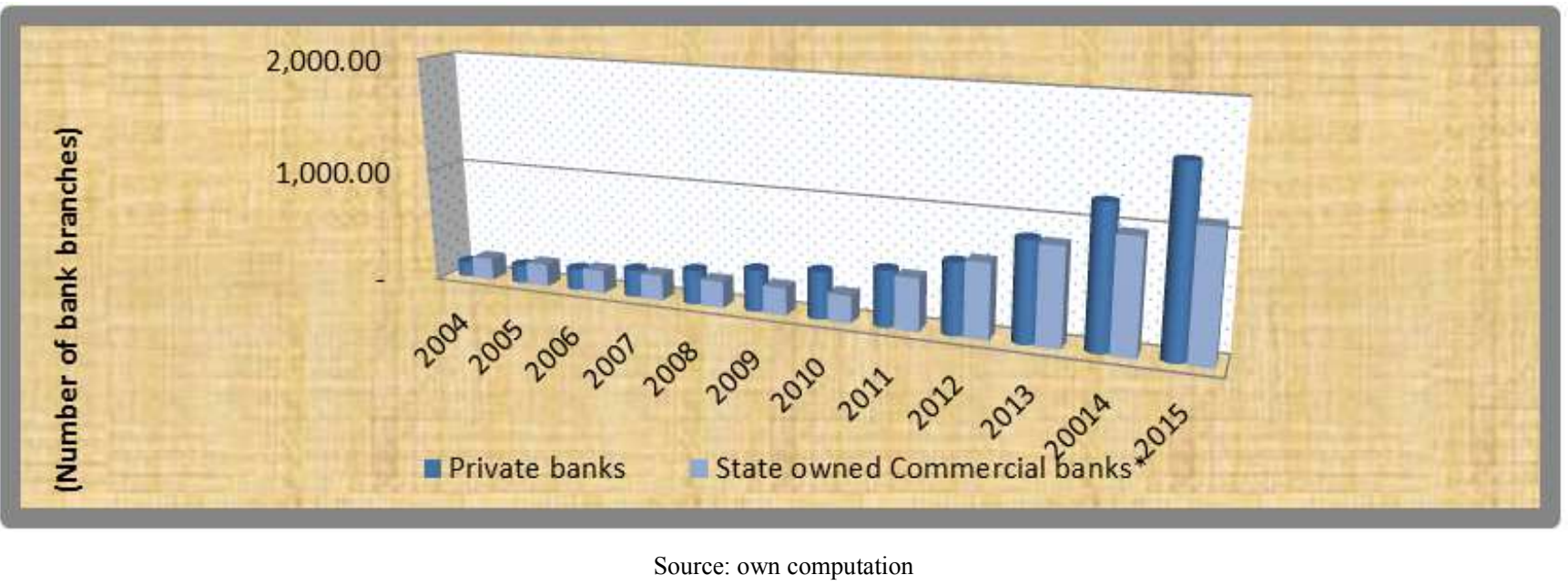

Figure 2. Time series of bank branches opened during the review period.

\subsubsection{Ownership Structure and Banks Profitability in Ethiopia}

At the time when the data for this paper was gathered, there were a total of eighteen domestic commercial banks operating in Ethiopia; of which sixteen were private commercial banks and the rest two were state owned banks. In spite of the infancy of banking industry in Ethiopia commercial banks were found to be profitable. On average the profitability of banks in Ethiopia were 3percent over the period (2010-2014) which is above the average SSA banks return on asset of 2 percent $^{3}$. As far as the ownership is

3 Working paper by(IMF) 2009 shows the average return on asset of SSA commercial banks were found to be 2 percent on average terms. concerned, the profitability (in terms of ROA and ROA) is not the same. For instance from the year 2010 to 2014 the ROA for private commercial banks were found to be above 3 percent on average which is more than ROA of publicly owned commercial banks which was slightly 3 percent on average. While ROE is higher for state owned commercial banks ${ }^{4}$ and net profit after tax was found to be increasing for private commercial banks over the assessment period (figure $3,4 \& 5)$.

4 State owned bank stands for commercial bank of Ethiopia and construction and business bank. 


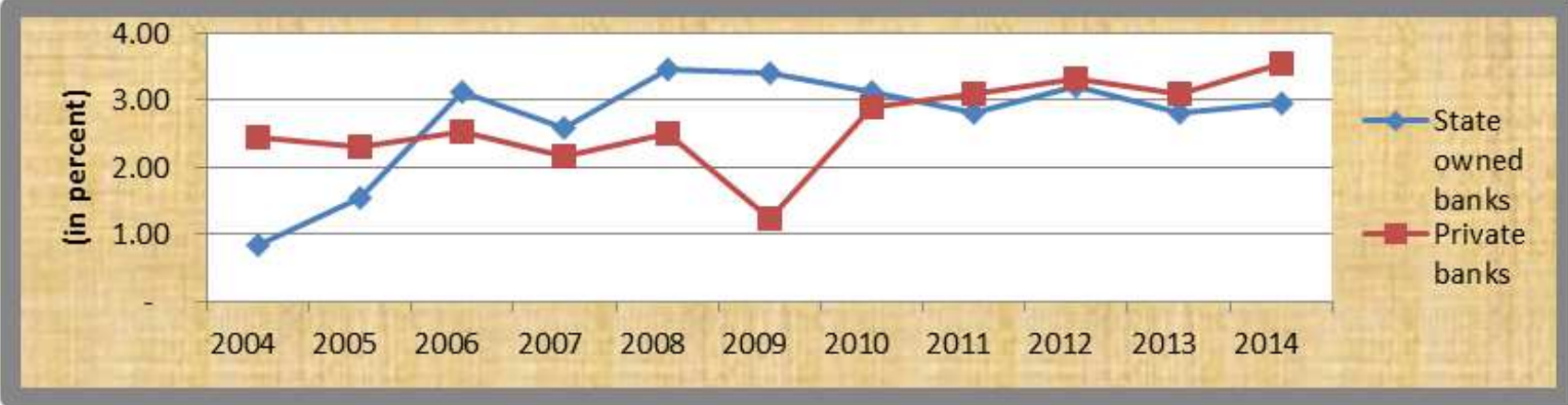

Source: own computation

Figure 3. Time series of Commercial banks ROA by ownership.

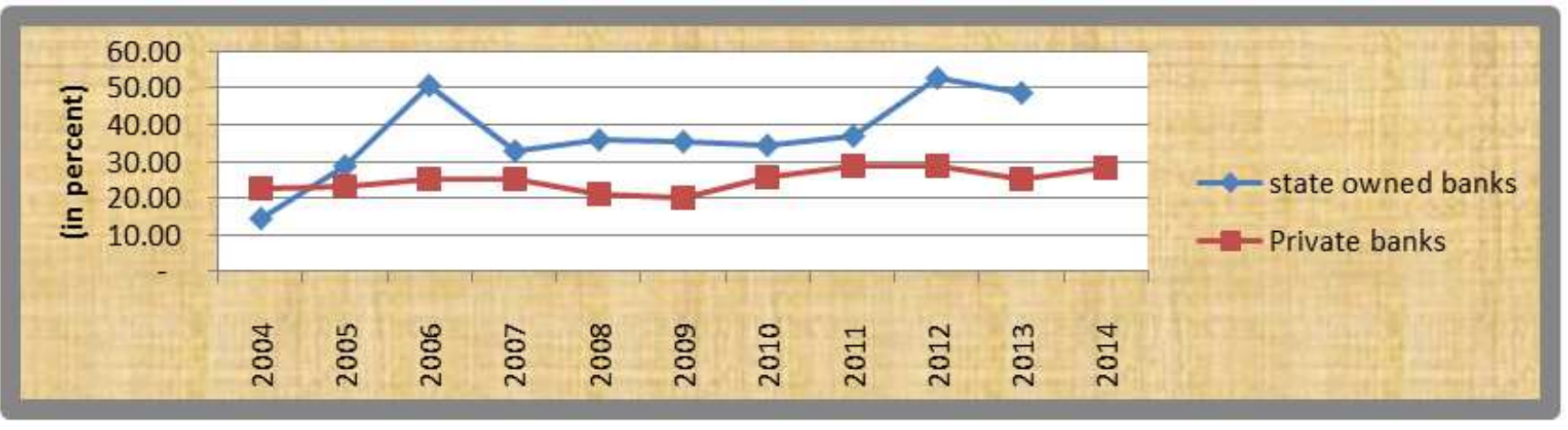

Source: own computation

Figure 4. Time series of Commercial banks ROE by ownership.

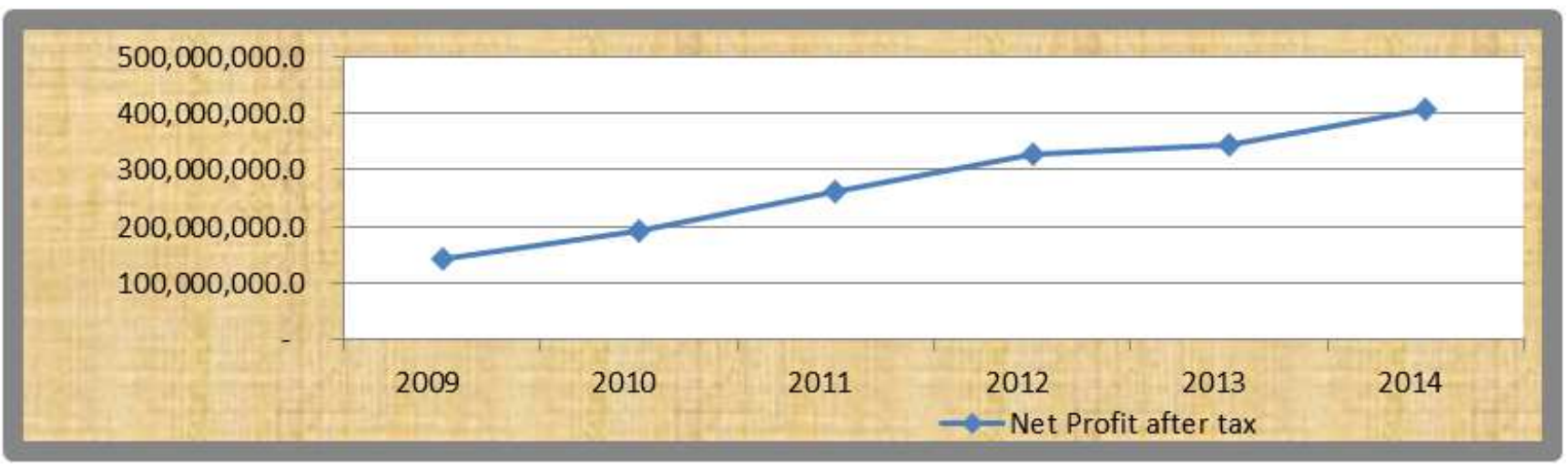

Source: own computation

Figure 5. Profit after tax trend for Selected Private Commercial banks.

\subsubsection{ROA and ROE for Ethiopian Commercial Banks}

As the data from 2004 to 2014 evidenced state owned banks return on asset were increase at an increasing rate and shoot to 3 percent at the year 2006 and volatile with a moderate trend and stays at 3 percent in 2014. While private commercial banks experienced below 3 percent ROA from 2004 until 2009 and even decline in 2009. But after 2009 ROA for private commercial banks gets increasing even above publicly owned commercial banks and reached 3.5 percent in 2014. As far as ROE is concerned state owned banks experienced good performance than privately owned banks. ROE for public banks reached 50 percent at the year 2013 while it was 30 percent for selected private commercial banks ${ }^{5}$ (figure 6 \&7).

5 selected banks means seven private banks that the researcher gather data for regression ( $\mathrm{AIB}, \mathrm{DB}, \mathrm{BOA}, \mathrm{WB}, \mathrm{UB}, \mathrm{NIB}$ and $\mathrm{CBO}$ ) 


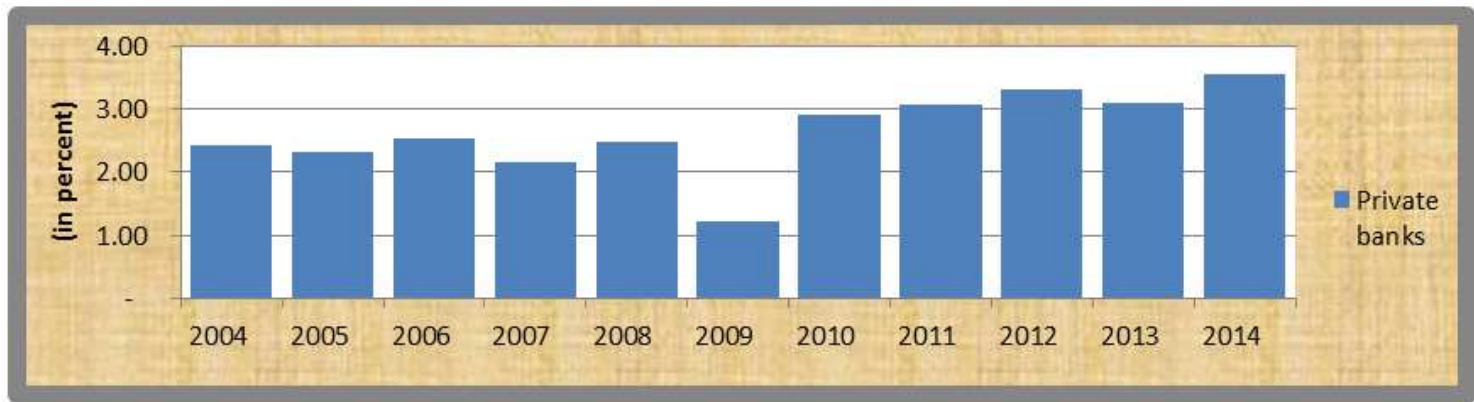

Source: own computation

Figure 6. Time series of Private Commercial banks average ROA.

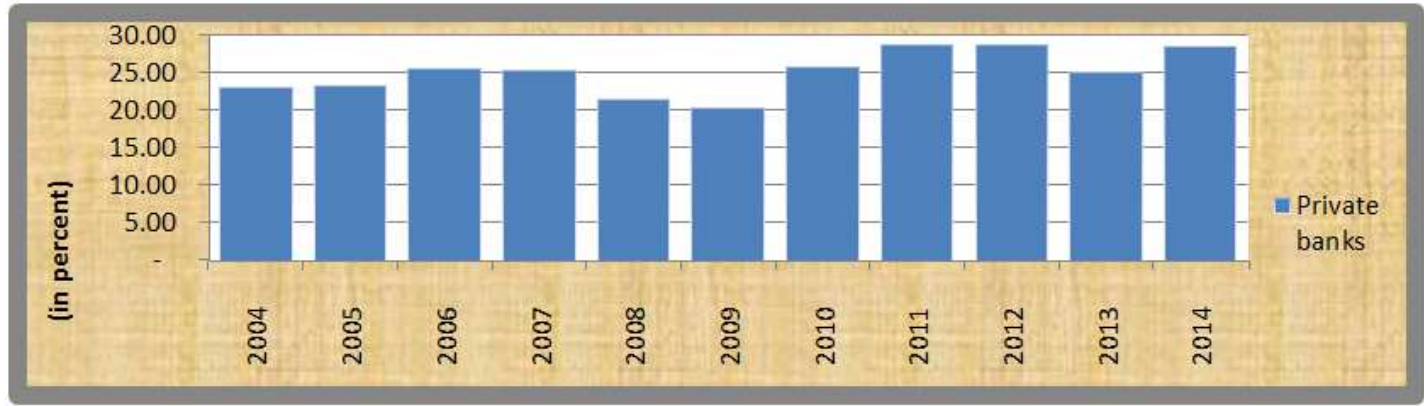

Source: own computation

Figure 7. Time series of Private Commercial banks average ROE.

The difference in ROA and ROE were seen not only among the ownership structure of banks but also it differs among each bank. For instance from the selected private commercial banks Wegagen Bank, Dashin Bank, Nib international bank and Awash International Bank experienced above 3 percent ROA for the study period. While cooperative bank of oromia experienced even below 2 percent. Dashen
Bank performs outstanding performance than other private commercial banks on ROE and it was on average above 35 percent over the study time, while the rest private banks perform below 25 percent. Exceptionally Cooperative Bank of Oromia experienced low performance on ROE and it was between 10 and 15 percent on average over the study period (figure $8 \& 9$ ).

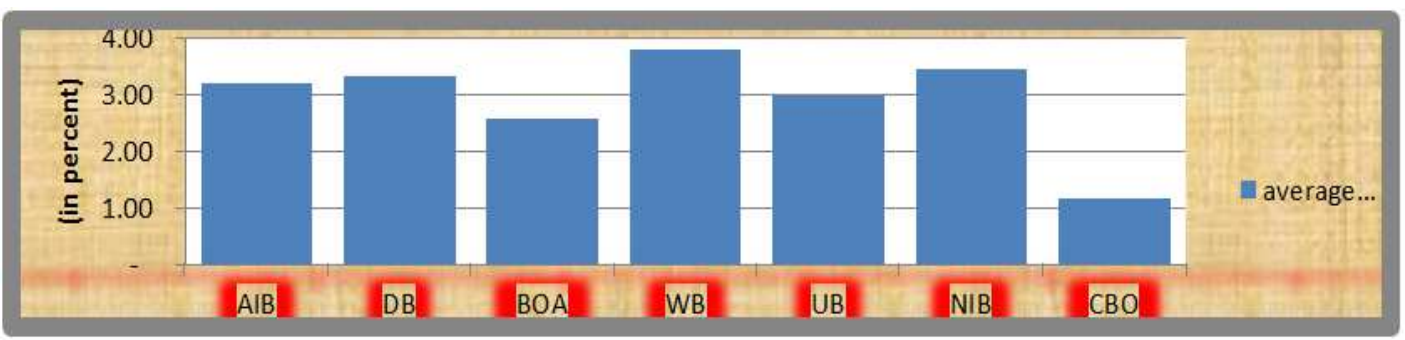

Source: own computation

Figure 8. Selected Private Commercial banks average ROA (2004-2014).

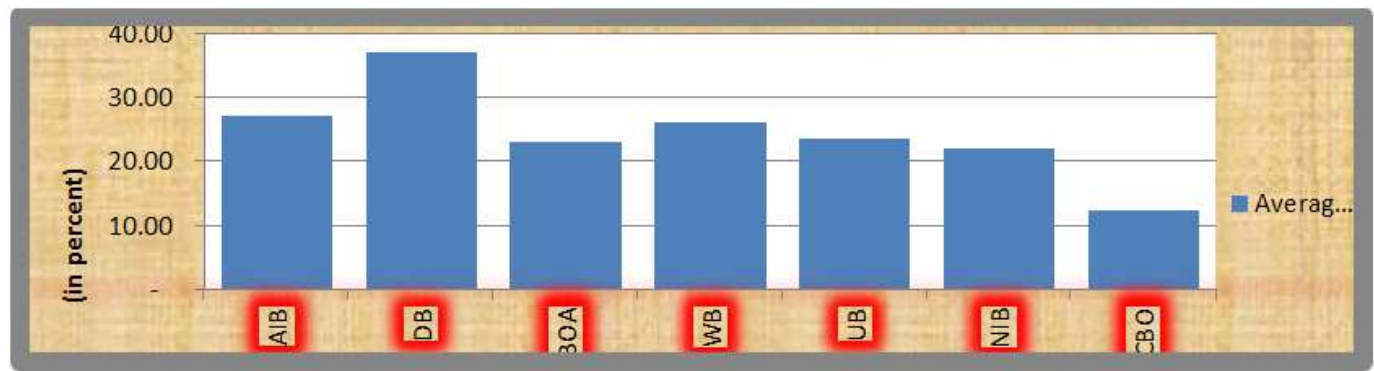

Source: own computation

Figure 9. Selected Private Commercial banks average ROE (2004-2014). 
Table 1 below presents the descriptive statistics of the variables considered under the model and to be tested. On average, the return on asset and return on equity of banks observed for this study is 3.02 and 25.022, respectively. Return on equity varies significantly across banks and periods; with standard deviation of 9.71 , while maximum and minimum values are 45.81 and -3.58 , respectively. Return on Asset also varies notably across banks and periods; with standard deviation of 1.23 , while maximum and minimum values are 5.10 and -2.37 , respectively. Likely, the value of explanatory variables varies across individual banks and periods with a significant deviation from the mean value.

Table 2. Descriptive statistics.

\begin{tabular}{llllll}
\hline Variable $\mid$ & Obs & Mean & Std. Dev. & Min & Max \\
\hline roe $\mid$ & 70 & 25.02261 & 9.706873 & -3.581 & 45.817 \\
roa $\mid$ & 70 & 3.023343 & 1.232238 & -2.374 & 5.101 \\
bs $\mid$ & 70 & 8.424229 & .9933682 & 4.86 & 9.997 \\
ldr $\mid$ & 70 & .9762571 & 1.076962 & .583 & 9.572 \\
bb $\mid$ & 70 & 54.01429 & 29.93108 & 6 & 152 \\
lci $\mid$ & 70 & .0324143 & .0160791 & .004 & .081 \\
irs | & 70 & 7.4015 & .510791 & 6.875 & 8.25 \\
gdpdgr | & 70 & 10.5677 & .8964236 & 8.7 & 11.795 \\
gdppci | & 70 & 7.0486 & 1.592375 & 4.468 & 9.694 \\
cpi $\mid$ & 70 & 17.24 & 10.85055 & 2.8 & 36.4 \\
\hline
\end{tabular}

\subsection{Econometrics Investigation}

Since the major objective of this paper is to assess the effect of Bank specific and macro-economic determinants on the profitability of private commercial banks of Ethiopia, we made panel econometrics investigation on bank specific and macroeconomics variables against banks return on asset (ROA) and (ROE). Here we have two panel econometrics models, the explanatory variables are the same across two models, whereas Return on Equity is taken as a dependent variable for the first model and Return on Asset is explained variable for the second panel model.

Before deciding between fixed or random effect models, we run a hausman specification test where the null hypothesis is the appropriate model is random effect and the alternative hypothesis is the preferred model is fixed effect. The conclusion is based on the probability value of the test. The hausman specification test results for our models are 0.97 and 0.81 . This indicates that random effect model is appropriate for both equations.

The estimated two equations fits the panel data reasonably well, as indicated by the Wald test statistic, which rejects the null hypothesis of joint insignificance of parameters. The Pesaran test of cross sectional independence also rejects the alternative hypothesis of there exists serial correlation.

Results from the regression with Return on equity as the dependent variable depicted in Table 2, below shows, the variable bank size, loan concentration index and interest rate spread is significant at 5\% level of significance while GDP growth rate is significantly affects return on equity at $10 \%$ level of significance. The magnitude is positive for bank size, loan concentration index and GDP growth rate. While, interest rate spread is negatively affects the return equity of private commercial banks in Ethiopia.

The second regression results with Return on asset as the dependent variable presented in Table 3, below shows, the variable bank size, loan to deposit ratio and interest rate spread are significant at 5\% level of significance while GDP growth rate and inflation is significant at $10 \%$ level of significance. The magnitude is positive for bank size, GDP growth rate and inflation. While, interest rate spread and loan to deposit ratio negatively affects the return on asset of private commercial banks in Ethiopia.

Bank size is the natural logarithm of banks total asset. As it is expected bank size positively and significantly affects the profitability (return on equity and return on asset) of private banks in Ethiopia. The result obtained from the regression of this study is in line with the result obtained by previous researchers [9] and [12]. The result supports economies of scale theory. Large banks have scale advantage and benefited there by reducing cost.

Loan concentration index has positive and significant effect on the return on equity of private banks and it has positive, but insignificant effect on banks return on asset. The result suggests banks having higher loan share from the total domestic credit to the country enjoy higher profit than those having small credit share.

Loan to deposit ratio has negative and significant impact on private banks ROA: the result is against the expectation and contrary to the work of other researchers. Logically Higher loan to deposit ratio indicates, commercial banks has issuing more of its deposit in the form of interest bearing loans, consequently banks can have generating more profit. But if the ratio is too high banks may default in the repayment of loan. Too low loan to deposit ratio is also a risk for commercial banks.

Interest rate spread also a main variable in determining the Return on asset and return on equity of private banks in Ethiopia and is significant at 5\% level of significance. The negative effect of interest rate spread on banks profitability (ROA \& ROE) is a controversial result and of against the reality. As indicated by previous researchers interest rate spread has positive and significant effect on commercial banks performance. The negative effect of interest rate spread on banks profitability observed in the regression, might be because of nonperforming loans and banks less competitiveness resulted from higher cost of credit. Banks with higher lending rate may fail to attract borrowers and borrowers may fail to repay their obligation.

As expected, output growth has a positive impact on banks ROA and ROE, significant at the 10 percent level, while GDP per capita does not seem to significantly affect private banks ROA and ROE.

The positive and significant impact of inflation on profitability might be from the larger difference between lending and deposit interest rate. Banks nominal lending interest rate is above inflation rate while, the deposit 
interest rate they bear is minimal (negative after adjusted with inflation): with higher inflation, the banks tend to charge higher nominal rates from their customers, capturing a larger spread between the rates at which they lend and the rates at which they borrow. This indicates that banks can predict future inflation and adjust their profit margin. The result is supported from previous researchers, (study by IMF, 2009 found positive and significant impact of inflation for sub Saharan Africa banks profitability).

As indicated by the value the goodness fit /R- square both models are well explained by between variation (across cross sections /banks) the between R- square is 0.89 and 0.73 for the first and second models, Whereas the overall $\mathrm{R}$ - square is found to be 0.61 and 0.56 , respectively.

Table 3. Random effect model taking ROE as a dependent variable.

\begin{tabular}{lllll}
\hline roe $\mid$ & Coef. & Std. Err. & $\mathbf{z}$ & $\mathbf{P}>|\mathbf{z}|$ \\
\hline $\mathrm{bs} \mid$ & 6.600662 & 2.513299 & 2.63 & $0.009^{* *}$ \\
$\mathrm{ldr} \mid$ & -.8345181 & .9252181 & -0.90 & 0.367 \\
$\mathrm{bb} \mid$ & -.0532552 & .0633775 & -0.84 & 0.401 \\
$\mathrm{lci} \mid$ & 209.4774 & 89.0272 & 2.35 & $0.019^{* *}$ \\
$\mathrm{irs} \mid$ & -9.246264 & 3.992328 & -2.32 & $0.021^{* *}$ \\
gdpdgr $\mid$ & 2.867962 & 1.630451 & 1.76 & $0.079^{*}$ \\
gdppci $\mid$ & 1.895745 & 1.170035 & 1.62 & 0.105 \\
cpi & .1406506 & .1033988 & 1.36 & 0.174 \\
cons $\mid$ & -11.34039 & 27.41439 & -0.41 & 0.679 \\
\hline
\end{tabular}

Wald chi2 $(8)=60.92$ R-sq: within 0.38 , between $0.89 \&$ overall $=0.61$ Prob $>$ chi2 $=0.0000$

Hausman specification test to identify, whether we use fixed or random effect model $\operatorname{chi} 2(7)=1.88$

Prob $>$ chi $2=0.9663$

Breusch and Pagan Lagrangian multiplier test for random effects chibar2 $(01)=0.07$

Prob $>$ chibar2 $=0.3921$

Pesaran's test of cross sectional independence $=-1.726, \operatorname{Pr}=0.0844$

Average absolute value of the off-diagonal elements $=0.406$

*,**, indicates statistical significance at $10 \%$ and $5 \%$, respectively.

Table 4. Random effect model taking ROA as a dependent variable.

\begin{tabular}{lllll}
\hline roa $\mid$ & Coef. & Std. Err. & $\mathbf{z}$ & $\mathbf{P}>|\mathbf{z}|$ \\
\hline $\mathrm{bs} \mid$ & .9403691 & .3300296 & 2.85 & $0.004^{* *}$ \\
$\mathrm{ldr} \mid$ & -.2645475 & .1181202 & -2.24 & $0.025^{* *}$ \\
$\mathrm{bb} \mid$ & -.0055899 & .0082776 & -0.68 & 0.499 \\
$\mathrm{lci} \mid$ & 1.608953 & 11.90607 & 0.14 & 0.893 \\
$\mathrm{irs} \mid$ & -1.079528 & .5154488 & -2.09 & $0.036^{* *}$ \\
gdpdgr $\mid$ & .3792499 & .2099463 & 1.81 & $0.071^{*}$ \\
gdppci $\mid$ & .2268579 & .1504274 & 1.51 & 0.132 \\
cpi $\mid$ & .0220348 & .0131942 & 1.67 & $0.095^{*}$ \\
cons $\mid$ & -2.387075 & 3.540915 & -0.67 & 0.500 \\
\hline
\end{tabular}

Wald chi2 $(8)=61.44$ R-sq: within 0.46 , between $0.73 \&$ overall $=0.56$ Prob $>$ chi2 $=0.0000$

Hausman specification test to identify, whether we use fixed or random effect model $\operatorname{chi} 2(7=3.73$

Prob $>$ chi2 $=0.8107$

Breusch and Pagan Lagrangian multiplier test for random effectschibar2(01)

$=4.76$, Prob $>$ chibar $2=0.1045$

Pesaran's test of cross sectional independence $=-1.414, \operatorname{Pr}=0.1573$

Average absolute value of the off-diagonal elements $=0.315$

$*, * *$, indicates statistical significance at $10 \%$ and $5 \%$, respectively.

\section{Conclusion and Recommendation}

\subsection{Conclusion}

The paper investigates the impact of bank specific factors namely, bank size, loan to deposit ratio, bank branch, loan concentration index, interest rate spread and macro-economic factors such as GDP growth rate, GDP per capita income and Inflation on the profitability of Ethiopian private commercial banks over the study period (2005-2014). To test the effect of such variables on banks profitability, we have used both descriptive and econometrics method of analysis. The descriptive part of the study presents trends of deposit share of private commercial banks, banks ownership and profitability trends and summery statistics for variables used under the model. For the econometrics part of the analysis we regress two equations, random effect panel data econometrics has been used. Hausman specification test result proofs random effect model is appropriate for both equations. The estimated two equations fit the panel data reasonably well, as indicated by the Wald test statistic and the Pesaran test of cross sectional independence also rejects the alternative hypothesis of there exists serial correlation. As it is indicated at the descriptive part of the analysis, the deposit share of private banks gets increasing and reached 30 percent of the total deposit, while its share was 10 percent of the total deposit since 2000. Private Banks were appeared to have high ROA than state owned banks and the reverse holds true for ROE.

Regression results with Return on equity as the dependent variable shows, bank size, loan concentration index and interest rate spread is significant at 5\% level of significance and GDP growth rate is significant at $10 \%$ level of significance. The magnitude is positive for bank size, loan concentration index and GDP growth rate. While, interest rate spread has negative effects on the return equity of private commercial banks in Ethiopia.

The second regression results with Return on asset as the dependent variable shows, bank size, loan to deposit ratio and interest rate spread are significant at 5\% level of significance while GDP growth rate and inflation is significant at $10 \%$ level of significance. The magnitude is positive for bank size, GDP growth rate and inflation. While, interest rate spread and loan to deposit ratio has negative effects on the return on asset of private commercial banks in Ethiopia.

\subsection{The Way Forward}

The conclusion for this study evidenced that both bank specific and macro-economic variables significantly explain the profitability of commercial banks in Ethiopia. Following from the whole finding of the paper, the researcher forwards the following policy recommendation for policy makers:-

- Since privately owned banks earn higher return (as measured by ROA) than state owned banks, creating conducive environment and letting private banks to be competitive could be vital to have sound banking 
system.

- Even if it needs further investigation, the significant and positive impact of Bank size can be taken as a good signal for commercial banks to merge and to have scale advantage.

- Since macro-economic variables such as, output growth and inflation were significant in explaining banks profit, policies that are designed to promote sustainable output growth and controlling inflation are good for banking sector stability.

- The negative impact of loan to deposit ratio on commercial banks profitability is a good signal for banks to have not too high or too low loan to deposit ratio.

- How loan to deposit ratio negatively affects private commercial banks profitability needs further investigation and it could be researched further.

\section{References}

[1] Ahmad Aref Almazaril (2014), Impact of Internal Factors on Bank Profitability: Comparative Study between Saudi Arabia and Jordan. Journal of Applied Finance \& Banking, vol. 4, no. $1,2014,125-140$

[2] AmerAzlan Abdul Jamal and MasyhuriHamidi, (2012), Determinants of Commercial Banks' Return on Asset: Panel Evidence from Malaysia. International Journal of Commerce, Business and Management (IJCBM), ISSN: 2319-2828, Vol. 1, No3, December 2012.

[3] Anteneh, TilahunMehari, and A. S. Chawla. "Determinants of Commercial Banks Profitability: Empirical Evidence from Ethiopia. ZENITH International Journal of Multidisciplinary Research 6.1 (2016): 79-89.

[4] Chioma, Adanma and Clementina (2014), Empirical Study of the Impact of Inflation on Bank Performance. Humanity\& Social Sciences Journal 9 (2): 61-71, 2014.
[5] Christos K. Staikouras and Geoffrey E. Wood, (2004), The Determinants Of European Bank Profitability. International Business \& Economics Research Journal, Vol 3, No 6 (2004).

[6] European Central Bank (2010), Beyond ROE - how to measure bank performance, Appendix to the report on EU banking structures.

[7] Flamini, V., McDonald, C. \& Schumacher, L. (2009). The determinants of commercial bank profitability in Sub-Saharan Africa, IMF Working paper WP/09/15.

[8] GODDARD, J. et al. (2004), the profitability of European banks: a cross-sectional and dynamic panel analysis. Manchester School, vol. 72, no. 3, pp. 363-381.

[9] HaroonJabbar, (2014,) Determinants of Banks Profitability. IOSR Journal of Business and Management (IOSR-JBM), Volume 16, Issue 1. Ver. IV (Jan. 2014), PP 109-113.

[10] Jaber J (2014), the Impact of Internal and External Factors on Commercial Bank Profitability in Jordan. International Journal of Business and Management; Vol. 9, No. 4; 2014.

[11] Kozo Harimaya and KazumineKond (2010), the Effects of Branch Expansion on Bank Efficiency: Evidence from Japanese Regional Banks.

[12] Samuel Alemu, (2015), Determinants of Commercial Banks Profitability: The Case of Ethiopian Commercial Banks.

[13] Susan MoraaOnuonga, (2014), The Analysis of Profitability of Kenya`s Top Six Commercial Banks: Internal Factor Analysis. American International Journal of Social Science Vol. 3, No. 5; October 2014.

[14] Waqas Tariq (2014), Determinants of Commercial Banks Profitability. International Journal of Accounting and Financial Reporting, Vol. 4, No. 2.

[15] Zimmerman (1996), the Determinants of European Bank Profitability. International Business \& Economics Research Journal, Volume 3, Number 6. 